УДК 81 '42

DOI https://doi.org/10.26661/2414-1135-2021-84-31

\title{
ФУНКЦІЇ СКАЛЬДИЧНОГО КЕННІНГУ У «МЛАДШЕЙ ЭДДЕ»
}

\author{
Романова Н. В. \\ доктор філологічних наук, дочент, \\ професор кафедри німецької та романської філології \\ Херсонський державний університет \\ вул. Університетська, 27, Херсон, Украӥна \\ orcid.org/0000-0002-7444-3811 \\ vissensvelt@gmail.com
}

Ключові слова: кеннінг, скальдичний кеннінт, структура, модель, елемент, семантика, функиія.
Статтю присвячено дослідженню функцій скальдичного кеннінгу у «Младшей Эдде». «Младшая Эдда» - підручник скальдичного мистецтва XIII століття, укладений ісландським скальдом Сноррі Стурлусоном та перекладений радянським лінгвістом О.О. Смірницькою російською мовою в 1963 році. Автор підручника детально описує й ілюструє поетичну мову скальдів - поетів-співаків без музичного супроводу. Основним стилістичним засобом поетичної мови вважають кеннінг. Природа кеннінгу гетерогенна й етнічно забарвлена, поєднує в собі два й більше поняття. Етимологія кеннінгу лишається відкритою. Передбачають логічний зв'язок із титулом наведеного вище підручника, назвою хутора Одді, де виховувався автор, та семантичний зв'язок із «поетикою», «поезією» або «бабусею», «прабабусею». Сюди додають також і метафору. Скальдичний кеннінг походить від еддичного кеннінга й означає «поетичне позначення», «заміна назви», «дво- або багаточленний замінювач іменника звичайного мовлення», «троп», «описовий поетичний зворот», «різновид метафори», «поетичний прийом», «складова частина ісландської поезії ХІІІ століття». Виокремлено три основні різновиди моделей скальдичних кеннінгів: 1) одно-, 2) дво- і 3) багатокомпонентні, визначено їхню семантику, що охоплює збірність, святість, число, рід занять (однокомпонентні моделі), узагальнення і множинність/ одиничність, інтимні стосунки, кревну спорідненість (двокомпонентні моделі), інтенсивність самостійного переміщення в повітрі, табуйованість одного 3 учасників невербального спілкування (багатокомпонентні моделі), розрізнено варіанти, а саме: відкеннінги, саннкеннінги й кеннінги для затемнення смислу. Доведено, що вибирання певного скальдичного кеннінга залежить від творчої уяви поета та прагматики поезії. Функції аналізованих кеннінгів розмаїті: від семіотичної, номінативної, будівельної, комунікативної, естетичної, інформативної, волютативної (вплив) до характерологічної, текстотвірної, світоглядної, образотворчої, трансформаційної, аксіологічної, функцій категоризації, прирощення смислу, накладання та затемнення інтерпретації образу. 
FUNCTIONS OF SCALDIC KENNING IN "YOUNGER EDDA"

\author{
Romanova N. V. \\ Doctor of Philological Sciences, Associate Professor, \\ Professor at the Department of German and Romancer Philology \\ Kherson State University \\ Universitetska str., 27, Kherson, Ukraine \\ orcid.org/0000-0002-7444-3811 \\ vissensvelt@gmail.com
}

Key words: kenning, skaldic kenning, structure, model, element, semantics, function.
The article is devoted to the study of the functions of skaldic kenning in the "Younger Edda". "Younger Edda" is a textbook of the 13th century skaldic art, compiled by the Icelandic skald Snorri Sturluson and translated into Russian by the Soviet linguist Olga Smirnitskaya in 1963. The author of the textbook describes in detail and illustrates the poetic language of skalds. Kenning is considered to be the main stylistic means of poetic language. The nature of kenning is heterogeneous and ethnically colored, combining two or more concepts. The etymology of kenning remains open. There is a logical connection with the title of the above textbook, the name of the village of Oddi, where the author was brought up, and a semantic connection with "poetics", "poetry" or "grandmother", "great-grandmother". A metaphor is also added here. Skaldic kenning is derived from eddic kenning and means "poetic notation", "name substitution", "two- or multi-syllable noun substitute", "trope", "descriptive poetic inversion", "a kind of metaphor", "poetic technique", "an integral part of Icelandic poetry of the thirteenth century". There are three main types of models of skaldic kennings: 1) one-, 2) two- and 3) multicomponent, their semantics are defined, covering collectivity, sanctity, number, occupation (one-component models), generalization and plurality/ singularity, intimate relations blood relationship (two-component models), intensity of independent movement in the air, taboo of one of the participants of nonverbal communication (multicomponent models), different options are distinguished, namely: otkennings, sankennings and kennings for obscuring the meaning. It is proved that the choice of a certain skaldic kenning depends on the creative imagination of the poet and the pragmatics of poetry. The functions of the analyzed kennings are diverse: from semiotic, nominative, constructional, communicative, aesthetic, informative, voluptuous (influence) to characterological, text-forming, ideological, pictorial, transformational, axiological, functions of categorization, increment of meaning, overlapping and obscuring the interpretation of the image.
Постановка проблеми. «Молодша Едда», «Едда», «Прозаїчна Едда», або «Сноррієва Едда» належить до всесвітньовідомих писемних пам'яток, написаних ісландським скальдом, прозаїком, історіографом, політиком Сноррі Стурлусоном. Рукопис відноситься до XIII ст., адресований скальдам-початківцям [13, с. 196]. Скальди - це норвезькі й ісландські поети IX-XIII ст., що пишуть і виконують скальдичну, або еддичну (анонімну) поезію [9, с. 128]. Під час співу цієї поезії музичні інструменти не використовувались.

Існує декілька версій «Молодшої Едди»: «королівська», ворміанська, упсальська, утрехтська, арнамагніанська. Між наведеними рукопи- сами є багато розбіжностей, особливо між упсальським та іншими. Деякі дослідники вважають, що упсальський рукопис $є$ оригіналом, але левова частка науковців схиляється до «королівської» й утрехтської версій [13, с. 185]. Російськомовний переклад зроблено 3 ««королівського» рукопису» радянським лінгвістом Ольгою Олександрівною Смірницькою [там само, с. 6, 185].

Поезія скальдів була не стільки високим мистецтвом у сучасному розумінні слова [10, с. 559], скільки «надвисокою», гіпертрофованою авторською творчістю. Сутність цієї творчості полягала в розшифруванні хитромудрих повідомлень $[13$, с. $213 \mathrm{f}]$ та констатації фактів, свідками яких були поети-співаки. 
У сиву давнину поезія була своєрідним механізмом виживання, або «дієвою» соціальною програмою адаптації до навколишнього світу: первісно поет звертався до богів із хвалебною піснею (драпою), розраховуючи на всебічну підтримку (над)природних сил [9, с. 134]. Із часом до звеличення богів додалось і уславлення можновладців, військових ватажків, воїнів-героїв тощо (віса), а також висміювання негативних рис людей або їхніх аморальних учинків (ніда). Отже, виникали особливі відносини між людиною творчою й богом, між людиною творчою і людиною статусною, між людиною творчою і магією. Творча людина намагалась наблизити бога, статусну людину й магію до себе, якщо вони задовольняли іiі потреби чи відповідали іiі інтересам, i, навпаки, дистанціювати, якщо не задовольняли. У ході цих особливих відносин і зароджувались нові поняття на кшталт кеннінга. Складність феномену кеннінгу засвідчують різноманітні підходи до розкриття його сутності. Так, активно досліджують історію і природу (М И. Стеблин-Каменский), структуру і семантику (И.В. Свердлов), словотвірний потенціал і мотивацію (Г.В. Мельниченко), специфіку перекладу (М.П. Баева), особливості емоційного навантаження (Н.В. Романова). Констатуючи певний прогрес у розробленні проблеми, необхідно звернути увагу на той факт, що функції скальдичного кеннінгу лишаються дотепер на периферії.

Метою статті $\epsilon$ 3'ясування основних функцій скальдичного кеннінгу в російськомовній «Младшей Эдде».

Для досягнення поставленої мети необхідно розв'язати такі дослідницькі завдання: 1) уточнити поняття «скальдичний кеннінг»; 2) виявити структурно-семантичні ознаки мовної одиниці; 3 ) розкрити роль кеннінгу в поетичному мовленні.

Нами усвідомлюється нереальність остаточного розв'язання зазначених вище завдань, оскільки мовні знаки мають специфічну ознаку «непаралельність плану вираження і плану змісту» [6, с. 176], корелюють із менталітетом, історією, культурою [12, с. 4f], перекладацькою діяльністю, що «відображає «свій» оригінал, який може суперечити наміру автора, загальноприйнятій концепції твору» [3, с. 10]: «Младшая Эдда»-произведение очень пёстрое и сложное по составу. Кое-что в ней настолько вычурно и формалистично, что вообще совершенно непереводимо (и поэтому в основном опущено в настоящем издании). Другое - и особенно «Видение Гюльви», - наоборот, настолько непосредственно и наивно, что трудно передаётся средствами современного литературного языка» [13, с. 183f].

Щиро сподіваємось, що “Еdda” Сноррі Стурлусона знайде своїх прихильників у напрацюванні перекладів українською мовою і наблизить досліджуване питання до остаточного розв'язання.

Об'єктом дослідження постають скальдичні кеннінги, предметом вивчення - їх функціонування у віршованому тексті.

Виклад основного матеріалу. Поняття «скальдичний кеннінг» походить від еддичного кеннінгу. Етимологія слова $E d d a$ незрозуміла. Передбачають логічний зв'язок із титулом книги Сноррі Стурлусона [8, с. 96], назвою хутора Одді, де виховувався автор, та семантичний зв'язок із «поетикою» $[13$, с. 185f], «поезією» або «бабусею» $[8$, с. 96]. Слово кеннінт розглядають також як метафору «замінного поняття» $[9$, с. 127 , 134]. Отже, загалом аналізоване явище може вказувати на поетичну або давню метафору.

Виходячи 3 реконструкції В.Г. Таранця [16, с. 207], Edda має значення «прабабуся». За таких міркувань еддичний кеннінг може мати значення «архаїчна метафора».

Наведені дефініції не вписуються в коло лексико-семантичних варіантів давньоісландського дієслова kenning - «знати, узнавати, сприймати, відчувати». Екстраполюючи генеральне значення наведеного елемента на реконструйовану семантику «прабабуся», отримуємо шукане поняття, а саме: «езотеричні знання». Ці знання орієнтують на систему сакральних кодів [7, с. 14] ісландської поетичної мови XIII ст. Під сакральним кодом розуміємо невелику групу слів, успадкованих давньоісландською мовою від індоєвропейської прамови, і алфавітну частину графічних символів - літер, за допомогою яких із прочитаних слів або словосполучень можна сформулювати ісландською мовою логічно осмислені терміни чи цілі речення [4]. Гадаємо, цей код відомий дуже вузькому колу посвячених скальдів, оскільки передається від покоління до покоління і є безцінним національним надбанням.

Стосовно скальдичного кеннінгу (далі - кеннінг), його трактують по-різному: «поетичне позначення», «заміна назви», «дво- або багаточленний замінювач іменника звичайного мовлення» [15, с. 42], «троп» [1, с. 111], «описовий поетичний зворот», «різновид метафори» $[11$, с. $94 \mathrm{f}]$, «поетичний прийом, що замінював звичайне зрозуміле слово красивою метафорою» [5]. Звідси випливає, що скальдичний кеннінг $€$ результатом номінативного процесу, який кваліфікують як лінгвістичні, лексичні, стилістичні дії й естетичну оцінку з лінійкою «гарне - негарне».

$\mathrm{y}$ царині емпіричного матеріалу кеннін $\epsilon$ однією зі складових частин поетичної мови [13, с. 105]. Поетична мова характеризується високим стилем, образністю, національними поетичними традиціями, нормативністю, стандартизацією, ліричністю [2, с. 97]. 
Кеннінг, за Снорі Струлусоном, має власну структуру. Ідеться про словосполучення двох теонімів, 3-поміж яких другий тотожний ознаці. Тобто поет повинен описати божество, дати йому зовнішні характеристики. Отже, кеннінг має характерологічну та текстотвірну функції.

\section{Наприклад:}

верховне божество давніх германців Одін трансформується в «Тюра победыl», або «Тюра повешенных», або «Тюра ноши», або «Тюра колесницьыл» (Тюр - один із синів Одіна. Він - найбільш відважний, сміливий, розумний $[13$, с. 45$])$. Водночас поетів-початківців християнського віросповідання застерігають щодо віри в язичницьких богів [там само, с. 105f], богів експресивних, емоційно неврівноважених, прагматично налаштованих $[14$, с. $61 \mathrm{f}]$. Цей факт підтверджує не лише мирне співіснування язичництва i християнства, але і специфічність останнього на теренах країни, конституює тісні зв'язки поета 3 навколишнім світом через духовну та психічну категорії, моральне ставлення до предмета зображення. У цьому контексті кеннінг реалізує світоглядну функцію.

Зауважимо, що структура наведеного кеннінгу має варіанти, як-от:

«всеотеи», «ас воронов», «Хрофта-Тюр», «супруг Фригг», «Третий», «тот, кого обнимала Гуннлёд», «друг Мимира», «противник Волка», «бог павиих», «испыттатель воинов», «вождь», «Хрофт», «владыка Хлидскьяльва», «быстрый в полёте», «отеи человечества», «сын Бестли», «сын Бора», «потомок Бури» [13, с. 106f].

Кожний із цих варіантів привносить найбільш значущі риси в образ Одіна, розширює, підсилює останній, висвітлює його глибинну семантику, що постає в декількох планах: сакральному, кількісному, психологічному, соціально-культурному, профанному. Тут виокремлюємо образотворчу функцію кеннінгу.

У структурі кеннінгів Одіна розрізняємо три основні різновиди моделей: 1) однокомпонентні: «всеотеи», «Хрофта-Тюр», «Третий», «вождь», «Хрофт»; 2) двокомпонентні, або традиційні: «ас воронов», «супруг Фригг», «друг Мимира», «противник Волка», «бог павших», «испьттатель воинов», «владыка Хлидскьяльва», «отеи человечества», "сынн Бестли», «сын Бора», «потомок Бури»; 3) багатокомпонентні: «быстрый в полёте», «тот, кого обнимала Гуннлёд».

Семантика кеннінгів однокомпонентних моделей апелює до 1) збірності; 2) святості; 3) числа; 4) роду занять, двокомпонентних - маніфестує: 1) узагальнення і множинність; 2) інтимні стосунки; 3) узагальнення й одиничність; 4) кревну спорідненість, багатокомпонентних - інформує про: 1) інтенсивність самостійного переміщення в повітрі; 2) табуйованість одного 3 учасників невербального спілкування.

Зафіксовано кеннінги поезії.

Наприклад:

«кровь Квасира», «корабль карлов», «мёठ карлов», «мёд великанов», «мёд Суттунга», «мёд Одина», «мёд асов», «великанов выкуп за отиа», «влага Одрёрира, Бодна и Сона», «влага скал Хнитбьёрг», «пожива, находка, ноша и дар Одина», "сохранившаяся в скалах волна, спасшая карлов», «питьё Двалина», «плата племени камней», «волна жителей скал», «плата повелителя асов», «выкуп за Гиллинга», «влага котла груза виселиџь»», «волна моря Одрёрира», «деяние Рёгнира», «волна Боди», «струг саксов скал», «семя Сон», «потоки скаль ликования друга Мимира», «находка Тунда», «добыча Видура», «творение восхваления», «прибой влаги груди воителя», «дар Гримнира», «море либо влага карлов», «жидкость котла Одина», «влага котла бремени виселицыљ» - усього 32 приклади [там само].

Як бачимо, семантика ідеального (поезія) замінюється на семантику матеріального (субстанція, предмети, продукти харчування, рідина, форма, гроші тощо), тобто кеннінг виконує функцію трансформації змісту.

Структуру кеннінгів поезії зводимо до двох різновидів моделей: двокомпонентної: «кровь Квасира», «корабль карлов», «мёд карлов», «мёд великанов», «мёд Суттунга», «мёд Одина», «мёд асов», «питьё Двалина», «деяние Рёгнира», «волна Боди», «семя Сон», «находка Тунда», «добыча Видура», «творение восхваления», «дар Гримнира»; багатокомпонентної: «влага скал Хнитбъёрг», «плата племени камней», «волна жителей скал», «плата повелителя асов», «выкуп за Гиллинга», «волна моря Одрёрира», «струг саксов скал», «жидкость котла Одина» (три елементи); «великанов выкуп за отца», «влага котла груза виселиџь»», «прибой влаги груди вочтеля», «море либо влага карлов», «влага котла бремени виселицы» (чотири елементи); «влага Одрёрира, Бодна и Сона», «потоки скаль ликования друга Мимира» (п'ять елементів); «пожива, находка, ноша и дар Одина», «сохранившаяся в скалах волна, спасшая карлов» (шість елементів).

Семантика кеннінгів поезії двокомпонентної моделі репрезентована такими підкласами, як: 1) субстанція неприродно малої людини; 2) водний засіб пересування для множинності; 3-4) продукт харчування множинності/одиничності; 5) технологія; 6) іменна стихія; 7) генетичний матеріал; 8) результат діяння; 9) мовленнєва діяльність; 10) чарівний подарунок; багатокомпонентної-відображає: 1) рідину множинності; 2-3) економічні відносини множинності/одиничності; 4-5) форму рідини множинності/одиничності; 
6) водний засіб пересування для множинності; 7) сакральне обмеження рідини; 8) межу сакральної рідини; 9) альтернативу водної акваторії i рідини множинності; 10) сакральну рідину; 11) диференціацію профанної рідини; 12) інтенсивність вияву емоційного стану; 13) синтез продукту харчування, фізичних дій та сакрального подарунка; 14) форма рідини у статиці, що врятувала життя множинності.

У зв'язку з обсягом статті кеннінги не ілюструємо, а обраховуємо, унаочнюючи в таблиці 1.

Порядок реєстрів релевантний їхній появі в поетичних текстах III частини «Язык поэзии» [13, с. 97-179]. Цікаво, що в кожному наступному реєстрі $\epsilon$ частка попереднього кеннінгу. Ця взаємопрониклива послідовність передана не лише на лексичному, а й на граматичному рівні: одно-, дво- і багатокомпонентні моделі. Останні всотують у себе традицію (міфи) і аномалію (поезію), що зумовлює появу багатьох інтерпретацій.

Загальний корпус реєстрів становить 57 позицій, виявлено 659 прикладів мовних одиниць, зокрема: боги аси (12 осіб, 120 кеннінгів), богині асині (4 особи, 26 кеннінгів), боги вани (2 особи, 13 кеннінгів), християнський Бог (1 особа, 18 кеннінгів), мова (3 випадки, 73 кеннінги), частини: a) світобудови (4 випадки, 73 кеннінги); б) тіла (14 випадків, 44 кеннінги), стихія (2 випадки, 9 кеннінгів), час (2 випадки, 9 кеннінгів), людина (2 особи, 128 кеннінгів), люди (1 особа, 5 кеннінгів), статус (1 випадок, 17 кеннінгів), метал (2 випадки, 47 кеннінгів), спеціальний одяг (1 випадок, 1 кеннінг), речовина (1 випадок, 1 кеннінг), бій (1 випадок, 11 кеннінгів), зброя (1 випадок, 26 кеннінгів), гроші (1 випадок, 3 кеннінги), засоби пересування (1 випадок, 20 кеннінгів), розум (1 випадок, 15 кеннінгів).
Символічним є кільцювання ініціального Одін та фінального розум реєстрів. Одін, за міфами, «живёт от века, и правит в своих владениях, а властвует надо всем на свете, большим $и$ мальмм» (тут і далі виділено нами - Н. Р.), «Всего же важнее то, что он создал человека и дал ему душу, которая будет жить вечно и никогда не умрёт, хоть тело и станет прахом или пеплом» [там само, с. 19], душа «зовётся также «мыслью», «памятью», "разумом» [там само, с. 177]. Маючи сакральну природу, кеннінги описують навколишній світ як відображення у самосвідомості скальда.

3 таблиці 1 видно, що найбільш активно функціонують кеннінги чоловіка, мужа, маловживаними постають кеннінги кольчуги, отрути, губ, зубів, помірно поширеними визнаємо кеннінги жінки. Домінування кеннінгів чоловіка, мужа пояснюємо епохою патріархату, соціальним статусом та родом занять - служіння конунгу, охорона можновладців, елітарних прошарків населення, військова справа чи інші дії (подорож, морський похід, битва, мисливство, перевірка зброї, судна).

Виокремлюємо кеннінги для створення ледве відчутного іронічного ефекту. Наприклад:

Локі називають «родичем и дядей, весенним попутчиком и сотрапезником Одина и асов», «гостем и украшением сундука Гейррёда», «родичем Слейпнира» (кінь Одіна) [13, с. 113].

Складні кеннінги містять два споріднені поняття. Наприклад:

чоловіків описують як «посохи меча», поєднуючи битву і зброю, у кеннінгі щита «град или дождь земли оружия» згадують інтенсивність битви та зброю [там само, с. 157].

Антонімічні кеннінги мають різний смисл i співвідносяться, очевидно, зі стилістичним контекстом.

Таблиця 1

Ресстр та частота функціонування слів, що мають кеннінги в «Языке поэзии»

\begin{tabular}{|c|c|c|c|}
\hline Слово & Слово & Слово & Слово \\
\hline Одін (25) & Локі (21) & жінка ( 44) & рот (2) \\
\hline поезія (32) & Фрігг (7) & золото (31) & губи (1) \\
\hline Top (25) & Фрейя (11) & кольчуга (1) & язик (3) \\
\hline Бальдр (7) & Сів (5) & отрута (1) & зуби (1) \\
\hline Нерд (5) & Ідунн (3) & срібло (16) & волосся на обличчі (2) \\
\hline Фрейр (8) & небо (17) & битва (11) & волосся на голові (3) \\
\hline Геймдаль (5) & земля (16) & зброя, обладунки (26) & серце (2) \\
\hline Тюр (4) & мope (34) & судно (20) & груди (2) \\
\hline Брагі (4) & сонце (6) & Христос (18) & душа (7) \\
\hline Відар (7) & вітер (5) & конунг (17) & рука (5) \\
\hline Валі (6) & вогонь (4) & люди (5) & нога (2) \\
\hline Гед (6) & зима (5) & платня (3) & мовлення (26) \\
\hline Улль (6) & літо (4) & голова (3) & голос (15) \\
\hline Генір (4) & чоловік, муж ( 84) & очі (8), вуха (3) & розум (15) \\
\hline
\end{tabular}




\section{Наприклад:}

«греческий конунг» указує на кесаря Міклагарда, «конунг Иерусалима» об'єктивує очільника Єрусалиму, «конунг Рима» вербалізує Римського імператора, «конунг людей» відносять до будьякого конунга [там само, с. 158].

Синонімічні кеннінги мають аналогічний смисл.

\section{Наприклад:}

«конунг конунгов» позначає кесаря та конунга великої держави, «раздающиче богатства» еквівалентні бондам шановного роду та конунгам [там само, с. 160].

Омонімічні кеннінги мають однакове звучання.

Наприклад:

«голос» $\mathrm{i}$ «нрав», «голос» $\mathrm{i}$ «урное расположение духа», «гнев человека» і «корабельные снасти либо лошадиная сбруя», «сустав, скрепляюший кости, корабль и войско», «помощьь, которую один человек оказывает другому» і «пиво» [там само, c. 179].

Різновидами кеннінгів є відкеннінги, саннкеннінги $\mathrm{i}$ кеннінги для затемнення смислу. Відкеннінги мислять, мабуть, як функціонально-стилістичні відповідники.

Наприклад:

людину називають за віковою ознакою: «отецз», «дед», «прадед», «ребёнок», «дитя», «потомок», «отпрыск»; за соціальною взаємодією: «брат», «единокровный», «единоутробныйџ, «родной», «братецџ», «братан»; за міжособистісними стосунками: «друг», «советчик», «единомылиленник», «собеседник», «сотоварищ)», «приятель», «спутник», «любимец», «неприятель», «недруг», «враг», «ворог», «истребитель»; за статусом: «когда мужа обозначают через его жильё, либо корабль, если у того есть имя, либо наделённое собственным именем имущество» [там само, с. 174f].

Саннкеннінги перекладач тлумачить як епітети [там само, с. 237].

Наприклад:

замість слова чоловік уживають «мудрец», «разумник», «златоуст», «мудрый советчик», «щедрый на сокровища», «знатный», «блестяuзий» [там само, с. 175].

Кеннінги для затемнення смислу схожі за семантикою, їх можна вживати в поезії так, «чтобы возникла двусмыслица и нельзя было понять, не подразумевается ли что-нибудь другое, нежели то, на что указывает предыдущий стих».

Наприклад:

«ворота в заборе», «бык» i «склон» [там само, c. 179].

Отже, кеннінг може виконувати також функцію прирощення смислу (складні слова), функцію затемнення інтерпретації образу (антоніми), функцію накладання (синоніми), функцію гомо- генності (омоніми), функцію категоризації (відкеннінги), аксіологічну функцію (саннкеннінги) та функцію двозначності (кеннінги для затемнення смислу).

Завершуючи стислий екскурс із питання про функції кеннінгу у «Младшей Эдде», зазначимо, що поряд i3 загальноприйнятими функціями слова - семіотичною, номінативною, будівельною, комунікативною, естетичною, інформативною, волютативною (впливу) та поезії - звеличення, вихваляння певного божества, потім певних конунгів, князів, військових ватажків, воїнів-героїв, згодом висміювання негативних рис характеру можновладців, елітарного прошарку населення, їхніх аморальних учинків і вад пересічної людини - на передній план виходять специфічні функції, як-от: характерологічна, текстотвірна, світоглядна, образотворча, трансформаційна, аксіологічна, функція категоризації, функція прирощення смислу, затемнення інтерпретації образу, накладання значень та двозначності.

Висновки. Кеннінги є своєрідним прошарком середньовічної ісландської поетичної лексики, утвореної скальдами для естетичної й емоційної насолоди, а також механізмом самовираження духовних запитів поета. Вони унікальні, неповторні, надзвичайно важливі для реконструкції світогляду митця i, ширше, етносу. Окрім того, відображають еволюцію етнічного мистецтва та творчої особистості. Кеннінги впливають на динамічність, гнучкість структури поетичного тексту, його образність і смисл, формують емоційне тло й орієнтують на індивідуально оформлену художню реальність.

Перспективи подальших розробок. Окреслена проблема $є$ перспективною для подальших досліджень. Актуальним уважаємо зіставний аналіз функціонування еддичних і скальдичних кеннінгів, що дасть змогу синтезувати загальне та виявити окремішнє.

\section{ЛІТЕРАТУРА}

1. Баева М.П. Особенности перевода кеннингов англосаксонской поэмы «Беовульф». Вестник Московского государственного областного университета. Серия «Лингвистика». 2016. № 4. C. 110-118.

2. Глазова О.С. Ліричний суб'єкт в американських віршованих текстах модерну і постмодерну. Нова філологія. Запоріжжя : ЗНУ, 2011. Вип. 46. С. 96-100.

3. Демецька В.В. Теорія адаптації: крос-культурні та перекладознавчі проблеми. Херсон : МЧП «Норд», 2006. 346 с.

4. Загублений всесвіт стародавньої культури. URL: https://uk-ua.facebook.com/permalink.php? story_fbid $=280754585449603 \& \mathrm{id}=15729375$ 
1129021\&substory index=0 (дата звернення: 16.03.2019).

5. Кеннінг. URL: https://uk.wikipedia.org/wiki/ Кеннінг (дата звернення: 15.03.2019).

6. Кочерган М.П. Загальне мовознавство. Київ : Академія, 2010. 464 с.

7. Кушерець B.I. Аналіз знання як стратегічного ресурсу трансформації суспільства (світоглядно-методологічний аспект) : автореф. дис. ... докт. філос. наук : 09.00.03. Київ, 2003. 41 с.

8. Левицкий В.В. Германские языки и древние германцы. Черновцы : Рута, 2004. 208 с.

9. Левицький В.В. Основи германістики. Вінниця : Нова книга, 2008. 528 с.

10. Літературознавчий словник-довідник / за ред. Р.Т. Громяка, Ю.І. Коваліва, В.І. Теремка. Київ : Академія, 2006. 752 с.

11. Мельниченко Г.В. Кеннінг як засіб збагачення словникового складу давньоанглійської мови. Актуальні проблеми філологічної науки: сучасні наукові дискусії : матеріали Міжнародної науково-практичної конференції, м. Одеса, 23-24 березня 2018 р. Одеса : Міжнародний гуманітарний університет, 2018. С. 94-95.

12. Мирошниченко В.В. Авторська концепція художнього твору: онтогенез і експансія (на матеріалі англомовної та французької україники). Запоріжжя : ЗДУ, 2003. 283 с.

13. МЭ: Младшая Эдда. Ленинград: Наука, 1970. $256 \mathrm{c}$.

14. Романова Н.В. Емоції у германській міфологічній спадщині. Нова філологія. Запоріжжя : ЗНУ, 2011. Вип. 46. С. 59-63.

15. Стеблин-Каменский М.И. Историческая поэтика. Ленинград : Издательство Ленинградского университета, 1978. $173 \mathrm{c}$.

16. Таранець В.Г. Діахронія мови. Одеса : Друкарський дім, 2008. 232 с.

\section{REFERENCES}

1. Baeva M.P. (2016). Features of Kenning's translation of the Anglo-Saxon poem "Beowulf" [Osobennosti perevoda kenningov anglosaksonskoy poemy "Beovulf"]. Bulletin of Moscow State Regional University. Series "Linguistics", 4. P. 110-118 [in Russian]

2. Hlazova O.Ye. (2011). Lyrical subject in American poetic texts of modern and postmodern [Lirychniy subyekt $\mathrm{v}$ amerykanskykh virshovanykh tekstakh modern I postmodernu]. New Philology, 46. P. 96-100 [in Ukrainian]

3. Demetska V.V. (2006). Adaption theory: cross-cultural and translation problems [Teoriya adaptatsii: kros-kulturni ta perekladoznavchi problemy]. Kherson : Nord. 346 p. [in Ukrainian]
4. (2019). The lost Universe of Ancient Culture [Zahubleniy Vsesvit starodavnyoi kultury]. URL: https://uk/ua.facebook.com/permalink.php?story fbid $=280754585449603$ $\& \mathrm{id}=1572937511 \overline{29021}$ \& substory inde $\mathrm{x}=0$ (date of application: 16.03.2019) [in Ukrainian].

5. (2019). Kenning [Kenninh]. URL: https:// uk.wikipedia.org/wiki/Kenning (date of application: 15.03.2019) [in Ukrainian].

6. Kocherhan M.P. (2010). General linguistics [Zahalne movoznavstvo] [in Ukrainian].

7. Kusherets V.I. (2003). Analysis of knowledge as a strategic resource for the transformation of society [Analiz znannya yak stratehichnoho resursu transformatsii suspilstva (svitohlyadno-metodolohichniy aspect]. Abstract of the dissertation of the doctor of philosophical sciences : 09.00.03. Kyiv. 41 p. [in Ukrainian].

8. Levitskiy V.V. (2004). Germanic languages and ancient Germans [Germanskie yazyki I drevnie germantsy]. Chernovtsy : Ruta. 208 p. [in Russian].

9. Levitskiy V.V. (2008). Basics of German studies [Osnovy hermanistyky]. Vinnytsya : Nova knyha. 528 p. [in Ukrainian].

10. Hromyak R., Kovaliv Yu., Teremko V. (eds.) (2006). Literary dictionary-reference book [Literatruroznavchiy slovnyk-dovidnyk]. Kyiv : Akademiya. 752 p. [in Ukrainian].

11. Melnychenko H.V. (2018). Kenning as a means of enriching the vocabulary of the English language [Kenning yak zasib zbahachennya slovnykovoho skladu davnyoanhliiskoi movy]. Current problems of philological science: modern scientific discussions : materials of the International scientific-practical conference, Odesa, 23-24 March 2018 year. P. 94-95 [in Ukrainian].

12. Myroshnychenko V.V. (2003). Author's concept of the work of art: ontogenesis and expansion (based on English and French Ukrainian) [Avtorska kontseptsiya khudozhnyoho tvoru: ontohenez I ekspansiya (na materiali anhlomovnoi ta frantsuzkoi ukrainyky]. Zaporizhzhya : ZSU. 283 p. [in Ukrainian].

13. (1970). ME: Junior Edda [Mladshaya Edda]. Leningrad : Nauka. 256 p. [in Russian].

14. Romanova N.V. (2011). Emotions in the Germanic mythological heritage [Emotsii u hermanskiy mifolohichniy spadschyni]. New Philology, 46. P. 59-63 [in Ukrainian].

15. Steblin-Kamenskiy M.I. (1978). Historical poetics [Istoricheskaya poetika]. Leningrad : University Press. 173 p. [in Russian].

16. Taranets V.H. (2008). Diachrony in Language [Diakhroniya movy]. Odesa : Drukarskiy dim. 232 p. [in Ukrainian, Russian and English]. 